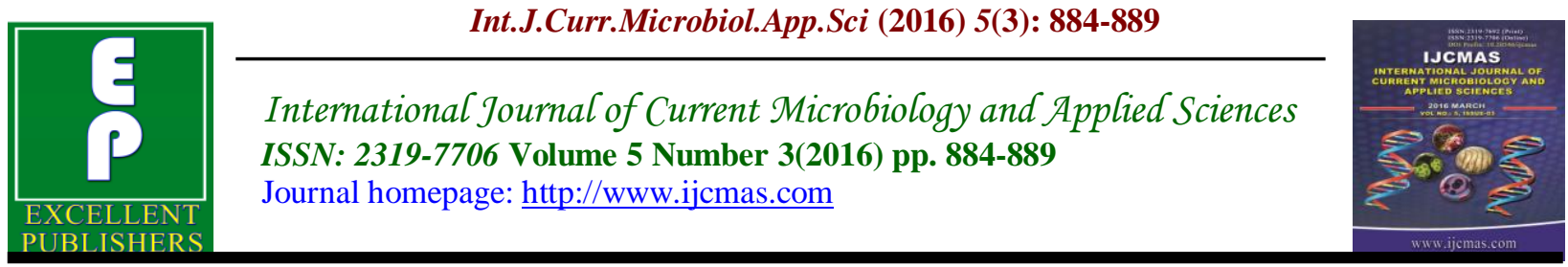

Original Research Article

http://dx.doi.org/10.20546/ijcmas.2016.503.102

\title{
Seasonal Variation in Plankton Diversity of Dhamapur Lake (Malvan) of Sindhudurg District (MS), India
}

\author{
D. S. Korgaonkar and D. L. Bharamal* \\ Department of Zoology, Shri Pancham Khemraj Mahavidyalaya, \\ Sawantwadi - 416510, (MS) India \\ *Corresponding author
}

\begin{abstract}
A B S T R A C T
Keywords

Plankton

diversity,

Dhamapur

lake.

Article Info

Accepted:

25 February 2016

Available Online:

10, March 2016

Plankton, the microscopic diversity hold the key role in designing the food web of aquatic ecosystem. Dhamapur Lake from Malvan taluka in Sindhudurg district was studied to understand seasonal variation in plankton diversity for duration of one year from January 2012 to December 2012. During the study, 10 phytoplankton species $(7$ species of class Chlorophyceae, 1 species of class Euglenophyceae and 2 species of class Myxophyceae) and 7 zooplankton species (4 species of Cladocera, 1 species of group Ostracoda and 2 species of group Rotifera) were recorded. Season wise highest diversity of both zooplankton and phytoplankton were observed in winter season. As compared to zooplankton, phytoplankton showed mark abundance in Dhamapur Lake.
\end{abstract}

\section{Introduction}

Planktons are microscopic life dwelling in water, drifting with water currents and floating freely in epilimnion due to limited locomotion. Planktons are further classified as Phytoplanktons which are the micro flora and Zooplankton including micro fauna (APHA, 1985). Phytoplanktons are the primary producers in any aquatic ecosystem. They act as food source for all the other secondary consumers in aquatic ecosystem. According to Benarjee and Narasimha(2013) phytoplanktons not only serve as food for aquatic animal but also play an important role in maintaining the biological balance and quality of water.

Whole aquatic life relies on phytoplankton population as they constitute the primary producers of most water bodies. Apart from forming an important food item of commercially important fishes, the phytoplankton communities have been extensively used as biological monitors from various parts of the world, Atazadeh et al, (2007). 
Phytoplanktons are followed by Zooplanktons. Aarti et al, (2013) states that zooplanktons too play an important role in the food chain, as they are second in trophic level as primary consumers and also contributes to the next trophic level. Trophodynamics, ecological energetics, cycling of material and aqua cultural productivity of water body is influenced by zooplanktons. Zooplanktons show diversified assemblage of taxonomically unrelated microscopic organisms and only the common ecological characteristic is this habitat, they are found freely in the epilimnion. Surve et al (2004) stated that occurrence and abundance of zooplanktons in the pond depends on its productivity which in turn is influenced by the physico chemical parameters and the level of nutrients.

Lentic ecosystems like ponds, lakes, etc harbor a rich biodiversity of the planktons as compared to the lotic ecosystems. Dhamapur Lake is a lentic ecosystem located in between Are and Katta village of Malvan taluka. It is a man- made lake and was constructed by the King Nagesh Desai in 1530. It has beautiful scenic hill ranges on its two sides with rich vegetation. The lake covers an area of about 22 hectares with the depth of about 12 meters. Dhamapur Lake receives water during monsoon season and remains full throughout the year, thus fulfilling the water requirements of the human civilization in its surrounding villages.

Freshwater ecosystems provide vital resources for humans and are the role habitat for an extra ordinarily rich and sensitive biota. Demands on freshwater ecosystems are increasing day to day, leading to large and growing threats to biodiversity around the world. As a result of this global crisis, documenting losses of biodiversity, diagnosing their causes and finding solutions have become major part of contemporary fresh water ecology research.

\section{Materials and Methods}

The water samples were collected in the first week of every month at the selected stations between 7:30 am to 10:00 am. The collection was done using conical plankton collecting net (diameter of mouth $-25 \mathrm{~cm}$, mesh size- $60 \mu \mathrm{m})$. Fixed volume of water (35 liter) was filtered through the conical plankton net and the samples of the plankton collected were concentrated to $25 \mathrm{ml}$ in glass bottle.

Planktons samples thus collected were preserved in Lugol's solution and trasported to the laboratory for the further analysis. The permanent preservation was done in $4 \%$ formalin. Identification and classification of planktons was done with the help of books by Edmondson (1959), Sarode and Kamat (1984), Battish (1992), Kodarkar(1992).

\section{Results and Discussion}

The data obtained during the study is presented in Table 1, Table 2 and Figure 1. Phytoplanktons play crucial role in aquatic ecosystem as they have the tendency to convert the radiant energy of sunlight into chemical energy. These phytoplanktons are consumed by the primary consumers and thus the stored energy is transferred to next trophic level in food chain. Hence study of planktons as far as their diversity, density, distribution is important to maintain water body healthy.

In the present study, phytoplanktons representing 3 classes were recorded at Dhamapur Lake in Malvan taluka. They were Chlorophyceae, Euglenophyceae and Myxophyceae. Representatives of Chlorophyceae showed maximum appearance then other two classes. Similar 
observations were also reported by Angadi et al (2005) in Papnash Pond, Bidar, Karnataka.

In the present study done Dhamapur Lake in Malvan taluka, 7 different genera of class Chlorophyceae viz; Chlorella sp., Microspora sp., Spirogyra sp., Pediastrum sp., Ulothrix sp., Volvox sp., Zygnema sp. were reported. Class Chlorophyceae were abundantly found in winter season while minimum count was recorded in summer season. Comparatively higher values of class Chlorophyceae were recorded in monsoon season than in summer season. Spirogyra sp. was the highest recorded genera in all season while Volvox sp. was lowest recorded in comparison to others.

Table.1 Seasonal Variation Shown by Phytoplanktons at Dhamapur Lake

\begin{tabular}{|c|c|c|c|c|}
\hline Class & Genera & Monsoon season & Winter season & Summer season \\
\hline \multirow[t]{8}{*}{ Chlorophyceae } & Chlorella sp. & 39 & 83 & 27 \\
\hline & Microspora sp. & 81 & 135 & 17 \\
\hline & Pediastrum sp. & 37 & 116 & 10 \\
\hline & Spirogyra sp. & 143 & 194 & 71 \\
\hline & Ulothrix sp. & 24 & 102 & 59 \\
\hline & Volvox sp. & 6 & 3 & 5 \\
\hline & Zygnema sp. & 86 & 125 & 56 \\
\hline & Total Count & 416 & 758 & 245 \\
\hline \multirow[t]{2}{*}{ Euglenophyceae } & Euglena sp. & 57 & 67 & 62 \\
\hline & Total Count & 57 & 67 & 62 \\
\hline \multirow[t]{3}{*}{ Myxophyceae } & Oscillotoria sp. & 80 & 141 & 86 \\
\hline & Nostoc sp. & 16 & 5 & 31 \\
\hline & Total Count & 96 & 146 & 117 \\
\hline \multicolumn{2}{|c|}{ Total Phytoplankton Count /ml } & 569 & 971 & 424 \\
\hline
\end{tabular}

Table.2 Seasonal Variation Shown by Zooplanktons at Dhamapur Lake

\begin{tabular}{|c|c|c|c|c|}
\hline Group & Genera & Monsoon season & Winter season & Summer season \\
\hline \multirow[t]{2}{*}{ Cladocera } & Bosmina sp. & 28 & 74 & 17 \\
\hline & Total Count & 28 & 74 & 17 \\
\hline \multirow[t]{4}{*}{ Copepoda } & Cyclops sp. & 29 & 89 & 37 \\
\hline & Mesocyclops sp. & 26 & 61 & 8 \\
\hline & Nauplius sp. & 20 & 667 & 18 \\
\hline & Total Count & 75 & 217 & 63 \\
\hline \multirow[t]{2}{*}{ Ostracoda } & Cypris sp. & 7 & 5 & 19 \\
\hline & Total Count & 7 & 5 & 19 \\
\hline \multirow[t]{3}{*}{ Rotifera } & Branchionus sp. & 12 & 47 & 16 \\
\hline & Keratella sp. & 4 & 15 & 4 \\
\hline & Total Count & 16 & 62 & 20 \\
\hline \multicolumn{2}{|c|}{ Total Zooplankton Count /ml } & 126 & 358 & 139 \\
\hline
\end{tabular}


Figure.1 Comparative Seasonal Variation in Phytoplanktons and Zooplanktons

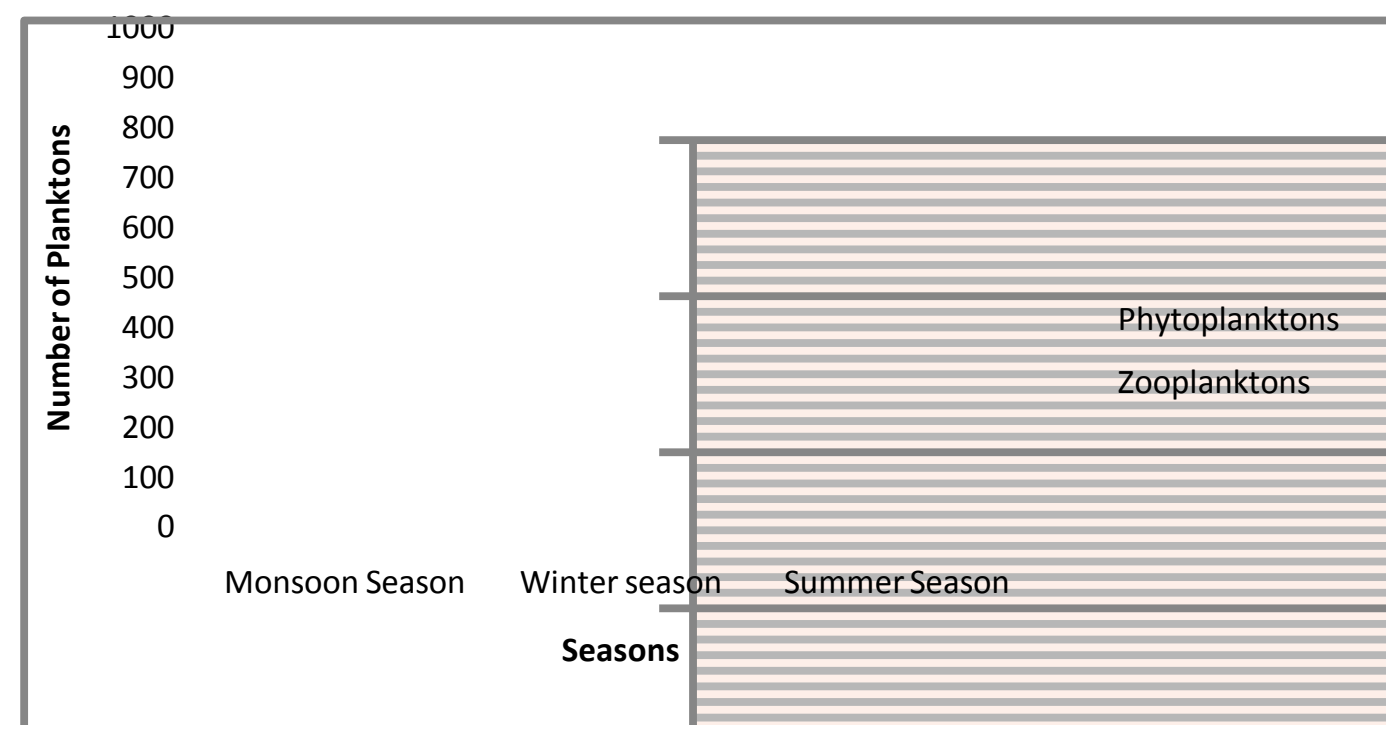

A single genus of class Euglenophyceae that is Euglena sp. was recorded. Higher values values were recorded in winter season while minimum values were recorded in monsoon season.

2 genera of class Myxophyceae were recorded. They were Oscillatoria sp. and Nostoc sp. Maximum values of class Myxophyceae were recorded in winter season while minimum values were recorded in monsoon season. Oscillatoria $s p$. was highest recorded in all seasons as compared to Nostoc $s p$.

Phytoplankton studies worldwide were also done by many researchers like Sirsath et al (2004); Sakhare and Joshi (2006); Bahura (2001); Reynoldson (1997); Zhang et al (2008); Hulyal and Kaliwal (2008).

Zooplanktons are minute members of second trophic level of food chain in aquatic life. During the present study 4 groups of zooplanktons were recorded. They were Cladocera, Copepoda, Ostracoda and Rotifera. Representatives of Copepoda showed maximum appearance then other 3 groups recorded.
A single genera, Bosmina sp. of group Cladocera was recorded. Higher values were recorded in winter seasons while minimum values were recorded in summer season.

3 genera namely Cyclops sp., Mesocyclops sp. and Nauplius sp. of group Copepoda were reported. Maximum values were reported in winter season while minimum values in summer season. Of the 3 genera, Cyclops sp. was higher as compared to other recorded species of the group.

Cypris sp. was the only one genera represented by group Ostracoda. Higher values were recorded in summer season while lower values in winter season.

Branchionus sp. and Keratella sp. represented group Rotifera. Higher values were observed in winter season while minimum values were observed in monsoon season. Branchionus sp. showed higher values in all seasons as compared to Keratella sp.

Zooplanktons studies worldwide were also done by many researchers like Sousa et al 
(2008); Rajeshekhar et al (2010); Pejavar and Gavrav (2008); Kiran et al (2007); Sharma and Hussain (2001).

To conclude, phytoplanktons are primary producers, the members of first trophic level, who play significant role in energy production and its circulation throughout the aquatic food web. Zooplanktons, the members of second trophic level are important link in aquatic food web and also help in energy transfer in ecosystem. The diversity, density and distribution of planktons are much influenced by environmental factors in which they live. Hence study of planktons can give a idea of water quality and can prove a good tool for monitoring and management of aquatic ecosystem.

\section{Acknowledgement}

Authors are thankful to the Principal, Head of the P. G. Department Zoology, of Shri Pancham Khemraj Mahavidyalaya, Sawantwadi for providing laboratory and library facilities and also encouraging for the research during the completion of the undertaken work.

\section{References}

Aarti, D., Sharma, K. K., Sharma, A. and Antal, N. 2013. Zooplankton Diversity and Physico-chemical Conditions of a Temple Pond in Birpur ( $\mathrm{J}$ and $\mathrm{K}$, India). Int. Res. J. Environ. Sci., 2(5):25-30.

Angadi, S. B., Shiddamallayya, N. and Patil, P. C. 2005. Limnological studies of Papanash Pond, Bidar (Karnataka). J. Env. Biol., 26(2):213-216.

APHA. 1985. Standard method for the examination of water and waste water. $15^{\text {th }}$ edition, New York, USA.

Atazadeh, I., Sharifi, M. and Kelly, M. G.
2007. Evaluvation of the Trophic Diatom Index for assessing water quality in River Gharasou, Western Iran. Hydrobiol., 589:165-173.

Bahura, C. K. 2001. Phytoplanktonic community of a highly eutrophicated temple tank Bikaner Rajasthan. J. Aqua. Biol., 16(1\&2):1-4.

Battish, S. K.1992. Freshwater zooplankton of India Oxford and IBH Publishing Co. pp:233. Benarjee, $\mathrm{G}$ and Narasimha, R. K. 2013. Physicochemical factors influenced plankton biodiversity and fish abundance- a case study of Nagaram tank of Warangal, Andhra Pradesh. Int. J. Lif. Sci. Biotech. And Pharma Res., 2(2): 248-260.

Edmondson, W. T. 1959.Freshwater biology (II Edition) by Ward, M. B. and Whipple, G. C., New York, John Villey and Son, 1-248.

Hulyal, S. B. and Kaliwal, B. B. 2008. Dynamics of phytoplankton in relation to physico-chemical factors of Almatti Reservoir of Bijapur district, Karnataka. Received 25 May 2007, online publication.

Kiran, B. R., Puttalah, E. T. and Kamath, D. 2007.Diversity and seasonal fluctuation of zooplankton in fish pond of Bhadra fish farm, Karnataka. Zoo's Print journal, 22(12):29352936.

Kodarkar, M. S. 1992.Methodology for water analysis, physico-chemical, biological and micro-biological parameters.Indian Association of Aquatic Biologists, Hyderabad. Publ.,2:50.

Pejavar, M. and Gurav, M. 2008.Study of water quality of Jail and Kalwa Lake, Thane, Maharashtra. J.Aqua. Biol., 23(2):44-50.

Rajashekhar, M., Vijaykumar, K. and Zeba, P. 2010. Seasonal variation of 
Zooplankton community in freshwater reservoir Gulberga district, Karnataka, South India, 2(1):6-11.

Reynoldson, T. B. (1997).Interaction between sediment contaminants and benthic organisms. Hydrobiologia, 149:53-66.

Sakhare, V. B. and Joshi, P. K. 2006.Plankton diversity in Yeldari Reservoir, Maharashtra.Fish.Chim.,23(12):23-25.

Sarode, S. T. and Kamat, N. D. 1984. Freshwater Diatoms of Maharashtra. Saikrupa Prakashan, Aurangabad, Maharashtra.

Sharma, B. K. and Hussain, M. 2001.Abundance and ecology of zooplankton in a Tropical Flood Plain Lake, Assam. Ecol. Env. and Cons. ,7(4):397-403.

Sirsath, D. B., Ambore, N. E. and Pulle, J. S. 2004.Study of phytoplankton of freshwater pond at Dharmapuri in Beed district. MS. J. Aqua. Biol., 19(2):7-10.
Sousa, W., Luiz, J., Elinez, A., Da silva, R. and Eskinazi-Santanna, M. E 2008. The response of zooplankton assemblages to variations in the water quality of four manmade lakes in semiarid northeastern Brazil. J. Plankton. Research, 30(6):699-708.

Surve, P. R., Ambore, N. E., Jadhav, S. S. and Pulle, J. S. 2004. Studies on zooplanktonic populations and their correlation with some physicochemical characteristics of Barul dam water. Nat. J. Lif. Sci., 1(2):193-198.

Zhang, M., Kong, F., Wu, X. and Xing, P. 2008.Different photochemical responses of phytoplankters from the large shallow Taihu Lake of subtropical China in relation to light and mixing. Hydrobiologia, 603:267278.

\section{How to cite this article:}

Korgaonkar, D. S., and Bharamal, D. L. 2016. Seasonal Variation in Plankton Diversity of Dhamapur Lake (Malvan) of Sindhudurg District (MS), India. Int.J.Curr.Microbiol.App.Sci.5(3): 884-889. doi: http://dx.doi.org/10.20546/ijcmas.2016.503.102 